\begin{tabular}{|c|c|c|c|c|}
\hline Date. & Digitalis. & $\begin{array}{c}\text { Inst rumental } \\
\text { records. }\end{array} \mid$ & $\begin{array}{l}\text { Rarial } \\
\text { pulse. }\end{array}$ & Rhythm. \\
\hline $\begin{array}{c}1913 . \\
\text { Aug. } 5\end{array}$ & None. & Electrocardio- & $\begin{array}{c}\text { Per min. } \\
105\end{array}$ & Normal. \\
\hline $\begin{array}{l}\text { Aug. } 25 \text { to } \\
\text { Sept. } 1 \text {. }\end{array}$ & $"$ & $\begin{array}{l}\text { graphic. } \\
\text { E.C.* }\end{array}$ & $150-160$ & $\begin{array}{l}\text { Auricular flutter; } \\
2: 1 \text { block. }\end{array}$ \\
\hline Sept. 1. & 3 ss. tr. dig. & - & - & - \\
\hline "2-3. & 3i. tr. dig. & Polygraphic. & $160-170$ & $\begin{array}{c}\text { Auricular flutter; } \\
2: 1 \text { block. }\end{array}$ \\
\hline " 4. & 3i. tr. dig. & $\begin{array}{c}\text { Polygraphic. } \\
\text { E.C. }\end{array}$ & 100 & $\begin{array}{c}\text { Auricular fibrilla- } \\
\text { tion. }\end{array}$ \\
\hline $\begin{array}{l}\Rightarrow \quad 6-9 . \\
" 11 .\end{array}$ & $\begin{array}{l}\text { 3i. tr. dig. } \\
\text { None. }\end{array}$ & $\begin{array}{l}\text { Polygraphic. } \\
\text { Polygraphic. }\end{array}$ & $65-75$ & tion. \\
\hline 12. & $"$ & $\begin{array}{l}\text { E.C. } \\
\text { Polygraphic. } \\
\text { E.C. }\end{array}$ & $\begin{array}{l}66 \\
82\end{array}$ & Normal. \\
\hline , $17-24$. & , & $\begin{array}{c}\text { Polygraphic. } \\
\text { E.0. } \\
\text { (See Fig. 3.) }\end{array}$ & $75-80$ & $\begin{array}{l}\text { Normal. Nume- } \\
\text { rous premature } \\
\text { contra ctions, } \\
\text { auricular, ven- } \\
\text { tricular, and } \\
\text { interpolated. }\end{array}$ \\
\hline ï 0.30 A.M. & $"$ & No tracing. & $1 \mathrm{CO}$ & Normal. \\
\hline $2 \mathrm{P} . \mathrm{M}$ & , & $\begin{array}{c}\text { Polygraphic. } \\
\text { E.C. }\end{array}$ & 110 & Auricular fibrilla- \\
\hline 3 P.M. & , & E.C. & 90 & $\begin{array}{l}\text { tion. } \\
\text { Normal. }\end{array}$ \\
\hline 5 P.M. & , & Polygraphic. & 144 & $\begin{array}{c}\text { Auricular fibrilla- } \\
\text { tion. }\end{array}$ \\
\hline 10 P.M. & , & $\begin{array}{c}\text { Polygraphic. } \\
\text { (See Fig. 4.) } \\
\text { E.C. } \\
\text { (See Fig. 2.) }\end{array}$ & $\begin{array}{l}110 \\
92\end{array}$ & $\begin{array}{l}\text { Auricular fibrilla- } \\
\text { tion. (Offset } \\
\text { recorded.) } \\
\text { Normal. }\end{array}$ \\
\hline $\begin{array}{l}\text { Sept. } 26-29 \\
30-\end{array}$ & , & Polygraphic. & $90-100$ & "1 \\
\hline 11.15 А.M. & $"$ & ", & 150 & $\begin{array}{l}\text { Auricular } \\
\text { flutter. }\end{array}$ \\
\hline 1.15 P.M. & " & $"$ & 126 & Auricular fibrilla. \\
\hline 2.45 P.M. & ", & E.C. & 104 & $\begin{array}{l}\text { tion. } \\
\text { Normal. }\end{array}$ \\
\hline 10 P.M. & , & Polygraphic. & 116 & $\begin{array}{l}\text { Auricular fibrilla- } \\
\text { tion. (Offset } \\
\text { recorded.) }\end{array}$ \\
\hline 10.20 P.M. & $"$ & " & 100 & Normal. \\
\hline Oct. $1-$ - & " & $"$ & 95 & ", \\
\hline 3 P.M. & , & " & 113 & Auricular fibrilla- \\
\hline 5 P.M. & " & , & 150 & $\begin{array}{l}\text { tion. } \\
\text { ?uricular } \\
\text { flutter. }\end{array}$ \\
\hline $\begin{array}{l}\text { Oct. 4- } \\
11 \text { A.M. }\end{array}$ & , & $"$ & 94 & Normal. \\
\hline $\begin{array}{l}9.30 \text { Р.M. } \\
\text { Oct. } 5-\end{array}$ & " & , & 138 & $\begin{array}{c}\text { Auricular fibrilla- } \\
\text { tion. }\end{array}$ \\
\hline $\begin{array}{l}\text { Oct. 5- } \\
10.30 \text { А.M. }\end{array}$ & $"$ & " & 97 & Normal. \\
\hline $\begin{array}{l}\text { Oct. 6-... } \\
11 \text { A.M. }\end{array}$ & " & $" 9$ & 98 & , \\
\hline 10 P.M. & " & $"$ & 135 & Auricular fibrilla- \\
\hline 0ct. 7. & " & " & 94 & Normal. \\
\hline 9 P.M. & $"$ & $"$ & 146 & Auricular fibrilla- \\
\hline Oct. $9-10$ & " & $"$ & $95-100$ & $\begin{array}{l}\text { tion. } \\
\text { Normal. }\end{array}$ \\
\hline 10.20 A.M. & $"$ & " & 140 & $\begin{array}{c}\text { Auricular fibrilla- } \\
\text { tion. }\end{array}$ \\
\hline 9 р.м. & " & $"$ & 91 & Normal. \\
\hline 0ct 13. & $"$ & 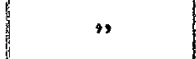 & 135 & Auricular fibrilla- \\
\hline $\begin{array}{l}14-22 . \\
23-\end{array}$ & ", & , & 100 & $\begin{array}{l}\text { tion. } \\
\text { Normal. }\end{array}$ \\
\hline $10.20 \mathrm{A.M}$ & ", & $"$ & 150 & $\begin{array}{c}\text { Auricular fibrilla- } \\
\text { tion. }\end{array}$ \\
\hline 9 P.M. & ", &, & 102 & Normal. \\
\hline Oct. 28. & ", & $\begin{array}{l}\text { Polygraphic. } \\
\text { E.C. }\end{array}$ & 161 & $\begin{array}{l}\text { Auricular flutter; } \\
2: 1 \text { block. }\end{array}$ \\
\hline " 29. & 3i.tr. dig. & Polygraphic. & 165 & ," \\
\hline 130. & 3i.tr. dig. & $\begin{array}{c}\text { Polygraphic. } \\
\text { F.C. } \\
\text { (See Fig. 1.) }\end{array}$ & 160 & , \\
\hline "11 $31-$ A. & 3i. tr. dig. & Polygraphic. & 112 & $\begin{array}{c}\text { Auricular fibrilla- } \\
\text { tion. }\end{array}$ \\
\hline 4 P.M. & 3i.tr. dig. & E.C. & 107 & Nermal. \\
\hline Nov. 3-30. & $\begin{array}{l}\text { Tr. dig. } \\
\text { stopped on } \\
\text { Nov. } 3 .\end{array}$ & $\begin{array}{c}\text { Polygraphic. } \\
\text { E.C. }\end{array}$ & $85-95$ & , \\
\hline
\end{tabular}

place under digitalis to auricular fibrillation on two occasions. An intervening period of normal rhythm was interrupted by numerous paroxysms. of auricular fibrillation.

I am indebted to Dr. John Parkinson for assist ance in the preparation of this article.

\title{
THE BACILLUS OF BOVINE TUBERCLE AS A FACTOR IN PHLYCTENULAR AFFECTIONS OF THE EYE. ${ }^{1}$
}

BY SYDNEY STEPHENSON, M.B. EDIN., F.R.C.S. EDIN, D.O. OXON.,

OPHTHALMIC SURGEON TO THE QUEEN'S HOSPITAL FOR CHILDREN, LONDON.

THE close relationship subsisting between phIyctenular affections of the eye on the one hand and "scrofula" or "struma" on the other has been known from early times, and was mirrored forth in the names "scrofulous" or "strumous ophthalmia" bestowed upon the disease by the older writers. After the discovery by Robert Koch in 1882 of the tubercle bacillus the clinical use of the word "scrofula" or "struma" became much restricted, if not actually abandoned. That tendency, as might be expected, was reflected in the nomenclature of the eye disease under discussion. The suggestion made many years before by the famous Dr. William Mackenzie, of Glasgow, that for the word "strumous" the word "phlyctenular" should be employed was very generally adopted in this country, and is so still. One never hears of "strumous ophthalmia" in England nowadays. Some of us, however, remained keenly alive to the fact that the ocular disease was frequently associated with the symptoms once termed "scrofulous," but now generally spoken of as "tuberculous."

About 14 years ago ${ }^{2}$ I published an account of my personal investigations into the etiology of what may conveniently be termed "phlyctenulosis." Among a total of 669 such cases I found tubercle to be present in 214 , or 31.98 per cent. A family history of tubercle was obtained in 72 per cent. of about 800 cases of phlyctenulosis. For purposes of comparison this could be got in $49^{\circ} 72$ per cent. of 181 non-ophthalmic out-patients at the Evelina Hospital, London, and in 35 per cent. among 200 such children at the Queen's Hospital for Children, London. These facts and some others led me to express the opinion that a well-marked tendency to phlyctenulosis was to be regarded as indicating that the patient was, or was likely to become, tuberculous.

The general accuracy of my figures was borne out by those published by Dr. Vilmos Leitner some five years later. ${ }^{3}$ Leitner found scrofulosis to be present in $45^{\circ} 1$ per cent. of 371 children with various diseases of the conjunctiva, as against 88.7 per cent. of 585 children with phlyctenular affections of the conjunctiva. A few years later Dr. L. Weekers, of Liége, found active tuberculosis in 36 per cent. of his 156 phlyctenular cases, while a family history of tubercle was forthcoming in 56 per cent. ${ }^{4}$ With the introduction of the various biological tests for tubercle, the opinion formed on purely clinical grounds has been confirmed, extended, and strengthened.

I A paper read before the Oxford Ophthalmological Congress on July 10th, 1914

2 Medical Press and Circular, Oct. 10th, 1900 3 Zeitschrift fur Augenherlkunde, Julv, 1905 4 Bulletin de l'Académie Royale de Médecine de Belgique, vol. xxiii. 909 , No. 9 . 
In 1907 I applied the Calmette tuberculin test to the eyes of 6 children, all of whom were affected with long-standing and relapsing ulceration of the cornea, diagnosed as of phlyctenular type. ${ }^{5}$ of these patients two alone manifested obvious tuberculous lesions in other parts of the body. Yet the ophthalmo-reaction was obtained in all of them. Aubaret and Lafon ${ }^{6}$ had previously elicited the Calmette reaction in 4 healed cases of phlyctenular disease. Since those early experiments other observers have found that by this method the reaction can be obtained in from 80 to 100 per cent. of the cases of phlyctenulosis.

As regards the injection of tuberculin, in 1907 I obtained a positive general reaction in 4 children suffering from phlyctenulosis. W. Stock ${ }^{7}$ had a general reaction in 87 per cent. of 23 patients with phlyctenulæ of the cornea. Weekers ${ }^{8}$ obtained a general reaction in 10 cases of phlyctenulosis after the subcutaneous injection of tuberculin, and a focal reaction was observed in 8 of the cases.

The results obtained by Dr. George S. Derby with the von Pirquet method were of considerable importance. $^{9}$ of 43 instances of phlyctenulosis 89 per cent. reacted to the tuberculin, while in nearly 80 per cent. physical examination disclosed evidence of tuberculosis. Weekers ${ }^{10}$ obtained a positive cuti-reaction in 91 per cent. of 156 children suffering from phlyctenulosis. In passing, it may be said that the test was positive in only 11 per cent. of the children not affected with phlyctenulosis. The experiments made with von Pirquet's test by Dr. J. A. Jamieson and myself ${ }^{11}$ may be briefly quoted. We employed the method in 20 patients, whose ages were from 2 to 12 years, and found that the cutaneous reaction was positive in every instance. A local reaction as regards the conjunctiva or cornea was observed in 8 of the patients. It should be added that 50 per cent. of these patients had more or less obvious signs of tubercle, medical or surgical, while a family history of tubercle was elicited in 75 per cent.

Finally, employing the Moro inunction method, Dr. H. H. Bywater, of Preston, ${ }^{12}$ obtained 16 positive results in 16 cases of phlyctenulosis, and Rosenbauch $^{13}$ in 50 such cases 96 per cent. of successes.

We may take it, then, that the association between phlyctenulosis and tubercle is proved on both clinical and biological grounds, and can no longer be doubted even by the most sceptical. The connexion, however, has recently entered upon a new and somewhat significant phase. It has been pointed out by Dr. Bywater that the subjects of phlyctenulosis respond to the specific tests for bovine tubercle. For example, in 15 juvenile cases of phlyctenular disease he had obtained a positive reaction in every instance to the Moro inunction test with bovine tuberculin. ${ }^{14}$ Twelve of these cases had been previously tested with human tuberculin, applied by the same method, and had reacted positively. In a latter communication ${ }^{15}$ Dr. Bywater stated that in 16 cases of typical phlyctenular disease in children

\section{Brit Med Jour Oct. 19th, 1907}

6 Gazette Hebdomadaire des Saiences Médicales de Bordeaux, August 4th, 1907.

ats Aetiologie der chronischen Entzindungen des ruges und seiner Adnexæ, Leipzig, 1907.

$$
\begin{gathered}
9 \text { Archives of Ophthalmology. September, } 1908 . \\
11 \text { Brit. Mer. Jour, April 16th, } 1910 . \\
12 \text { Thesis, 1911. }
\end{gathered}
$$

13_Von Graefe's Archiv für Ophthalmologie. Band lxxvi., 1910, p. 370. It The Ophthalmoscope, July, 1910. 15 Thesis, 1911 . from 3 to 17 years of age he had obtained positive results in every single instance, both with the human and the bovine product. In $56^{\circ} 25$ per cent. of the patients there was a family history of tubercle. No phthisis was present, but some other signs of tubercle were general in the children, especially enlarged glands.

Dr. Bywater's results appeared to me to be of considerable importance, and so, with the assistance of Dr. L. W. Jeffries, I have recently investigated the point at the Queen's Hospital for Children, London, in 20 children, aged from 17 months to 12 years, who were suffering from various forms of phlyctenulosis. Von Pirquet's method was adopted. In every case a positive result, both as regards bovine and human tuberculin, was obtained. The intensity of the reaction with the two products varied according to the particular patient. Thus, in one-half of the children the reaction was recorded as equal; in 6 the bovine exceeded the human reaction; and lastly, in 4 the reverse was the case.

That the conjunctival phlycten is not a tuberculoma is universally admitted. Nobody has yet succeeded in reproducing tuberculosis by inoculating the anterior chamber of susceptible animals with such products. Tubercle bacilli have not been found in the efflorescence. The lesion itself does not present the histological structure of tubercle. ${ }^{16}$ We may well ask ourselves in what way and by what means a focus of tubercle, latent or manifest, is able to produce a phlyctenule of the conjunctiva or cornea. Leber, as is well known, suggested that the phlyctenulæ were the direct result of dead bacilli set free from a caseous focus elsewhere in the body. The hypothesis was supported by a certain amount of experimental evidence. $\mathrm{He}$ found that an inflammation recalling phlyctenular keratitis sometimes followed the injection into the corneal parenchyma of dead tubercle bacilli. ${ }^{17}$ To this it has been objected that any foreign substance would do the same. Bruns (a pupil of Leber's) produced changes resembling phlyctenulæ by the injection of dead tubercle bacilli into the blood stream. $^{18}$

A somewhat similar view has been espoused by J. B. Nias and Leslie Paton ${ }^{19}$ on the ground that in upwards of 50 patients the opsonic index of the blood behaved in a way that was typical of a definite tuberculous infection. In an earlier communication, however, it is to be noted that those authors seemed to think that the condition must be assigned to "tubercle toxins circulating in the blood apart from their bacilli." 20

The best working hypothesis is probably that set forth with conspicuous ability by Dr. Weekersnamely, that the eye disease is due to the circulation of soluble toxins thrown off by the deposit of tubercle elsewhere in the body. The analogy that he institutes with the so-called "toxi-tuberculides" is very much to the point. Those eruptions, as is well known, occur in tuberculous subjects, and yet tubercle bacilli have not been found in them, neither can they be successfully inoculated into guinea-pigs. Exactly the same may be said of

16 Leber. almost alone among authors, has described the phlyctenule as possessing a tuberculous structure. The nodule, according to his investigations, is composed of polynuclear leucocytes, epithelioid cells and mans giant cells. The vessels of the part show endarteritis Caseation is not present.

1729 Berichte der Ophthalmologische Gesellschaft, Heidelberg, 1902, p. 66 .

19 Von Graefe's Archiv für Ophthalmologie, 1904, p. 439. Iy The Lancet, Dec. 1st, 1906, p. 1500

20 Transactions of the Ophthalmological Society of the United Kingdom, vol. xxri., 1906, p. 232. 
phlyctenulosis. Both the cutaneous and the ocular disease have on occasion been known to follow the subcutaneous injection of tuberculin (Hallopeau). The association of phlyctenulosis and of lichen scrofulosorum in one and the same subjects is, in my experience, not exactly an uncommon event. It may be reasonably suggested that such obvious tuberculous manifestations of the skin as scrofuloderma, lupus, and Bazin's disease (erythema in. duratum scrofulosorum) bear the same relationship to tubercle of the conjunctiva as is borne by lichen and acne scrofulosorum to phlyctenular affections.

The incidence of bovine tubercle as a cause of disease in human beings is known to vary greatly according to the locality. For example, as regards the Edinburgh district, Dr. A. P. Mitchell found bacilli of the bovine type in no less than 90.27 per cent. of 72 cases of cervical adenitis in children. ${ }^{21}$ On the other hand, in Berlin Gaffky found them in not more than 3.84 per cent. among 78 instances of tuberculous glands. Gosio examined the type of the bacillus in 122 cases of human tubercle, and found the bovine variety in 0.81 per cent. only. The infection of human beings by bovine bacilli, indeed, appears to be as rare an event in some cities, as Berlin, as it is common in others, as Edinburgh. The figures brought forward by Dr. Bywater and myself apply to two cities onlynamely, Liverpool and London. It will be interest. ing to see whether they are supported by returns from other cities of Great Britain.

If it can be shown that phlyctenulosis is usually associated with the bacillus of bovine tubercle, then the remedy lies at hand in the shape of a pure milk-supply. It is indeed possible that could such be secured by legislation, as at the moment appears to be very probable in England, phlyctenulosis might become one of the rarer affections of the eye in poor children instead of being, as it is at present, accountable for the vast majority of inflamed eyes in that class. The greatest cause of defective sight in childhood might be largely remedied. At all events, pending legislation, it would certainly seem advisable to sterilise raw milk before giving it to infants and children.

An even larger point, to which attention has been recently directed by an American physician, Dr. Louis C. Ager, of Brooklyn, should not be lost sight of. That observer urges that all children affected with phlyctenulosis should be submitted to expert physical examination for evidences of incipient tuberculosis, and that they should receive suitable treatment for that condition when present. ${ }^{22}$ That raises the question whether the ophthalmic surgeon can be said to have discharged his whole duty when he dismisses the child suffering from phlyctenulosis with a little good advice and a pot of yellow ointment.

Welbeck-street, $W$.

21 Brit. Med. Jour., Jan. 17th, 1914 ; THe LaveEr, March 7th, 1914, p. 674 .

22 Long Island Medical Journal, June, 1912.

Medical Magistrates. - Mr. Hugh Stott has just been placed on the commission of the peace for the county of Sussex. Mr. Stott, who resides at Lewes, is medical officer of health to the East Sussex combined districts. He held the office of Mayor of Lewes in 1911-12 and 1912-13. Dr. Sylvanus Glanville Morris, of Maerdy, Glamorganshire, has been placed upon the commission of the peace for the county of Glamorgan.

\section{A CASE OF FEMORAL HERNIA TREATED} BY BONE TRANSPLANTATION.

BY W. If. CI.AYTON GREENE, M.B., B.C. CANTAB, F.R.CS. ENG.,

SURGEON 'TO STT. MARY'S HOSLI'LAL, ETC.

From time to time surgeons have commented on the difficulty of dealing with the opening of a large femoral hernia. The method of approaching the neck of the sac from above Poupart's ligament and the subsequent suturing of the conjoined tendon to Cooper's ligament has given satisfactory results in ordinary cases, but where the opening is exceptionally wide other measures are required, and the implantation of filigree does not seem satisfactory in this situation.

The numerous articles recently published on the subject of bone grafting suggested to me the possibility of closing the entrance to the femoral canal by a bony transplant connected with the pelvis, and in this way increasing, as it were, the pelvic skeleton. The following is an account of a case in which the method was employed.

The patient, a male aged 57 years, was admitted to hospital with a double femoral hernia of about 14 years' duration. That on the right side was very large and caused great inconrenience; that on the left was smaller, but had recurred a year after an operation previously undertaken. (Fig. 1.) The

FIG. 1.

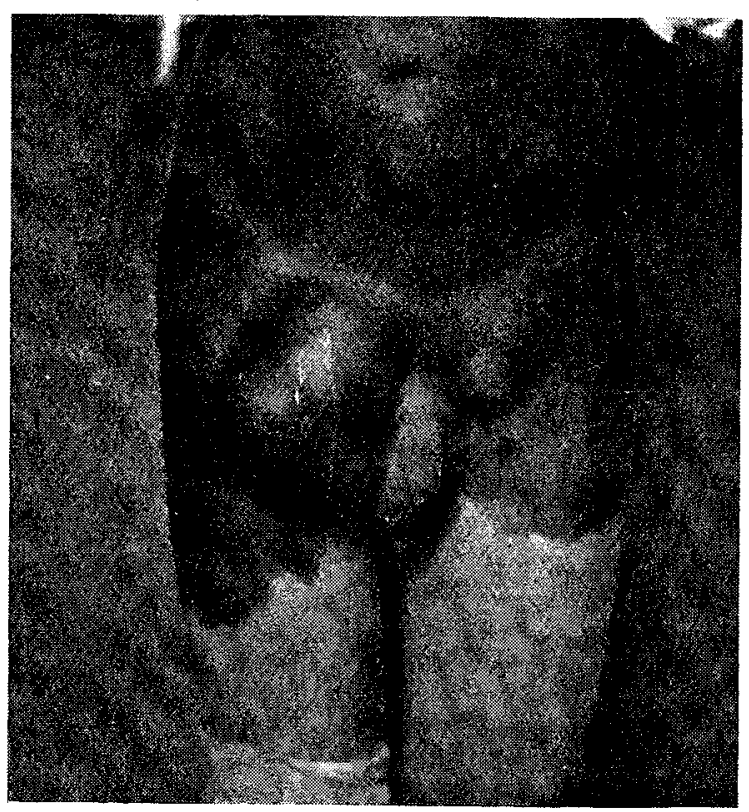

Large rigbt and small left femoral hernix.

right-sided swelling was reducible, and the whole hand could be introduced into the ring.

An operation was performed on May 28th when the sac was exposed by means of a transverse in. cision, the contents reduced, and the neck ligatured in the ordinary manner. About two inches of the eleventh rib were then excised subperiosteally and the bone was split into two pieces through the cancellous tissue. The femoral wound was then widely retracted and the bone grafts were introduced into pockets made in the periosteum at the back of the pubic bone. There was no trouble in fixing them, and Poupart's ligament was then drawn down to the pectineus fascia, leaving a firm bone plate on its abdominal aspect. The left hernia was dealt with by the ordinary method. The wounds healed soundly and the bone transplant can be felt c 2 